\title{
ENVIRONMENTAL ASPECTS IN THE SUBJECT TECHNIQUE
}

Jana BIL ČÍKOV $\boldsymbol{A}^{*}$, Univerzita Konštantína Filozofa v Nitre, Slovensko Ivana TUREKOVA, Univerzita Konštantína Filozofa v Nitre, Slovensko Alexander BILČ́ÍK, VŠ DTI, Dubnica nad Váhom, Slovensko

Přijato: 10.12.2019 / Akceptováno: 31. 3. 2020

Typ článku: Výzkumný článek

DOI: $10.5507 /$ jtie.2020.005

Abstract: The environmental education is a cross-cutting theme that can be implemented into every educational subject. The aim of the paper was to find out from 123 pupils of the first year of SOŠE in Trnava in the school year 2019/2020 the experience with the completed lessons of Technique at their primary school and the environmental topics they met there. The authors also examined the opinions of pupils from the completed Technique lessons at elementary school about working with implements, tools and machines, about developing their creativity by designing and producing/ manufacturing their own products. A questionnaire survey was carried out. A question to find out how they remember the environmental topics discussed in the lessons of Technique showed that $63.3 \%$ of respondents did not learn or do not remember the area of environmental topics from Technique lessons. Most of the positive answers, $12.5 \%$ of respondents, said that they remember waste sorting from environmental issues. At the end of the article, the authors pointed out the reasons why the cross-cutting themes of the environment are not effectively and visibly implemented at primary schools and also the role of teachers in improving the environmental readiness of pupils.

Key words: Environmental Education, Technique, Cross - cutting Theme

\section{ENVIRONMENTÁLNE ASPEKTY V PREDMETE TECHNIKA}

Abstrakt: Environmentálna výchova je prierezovou témou, ktorá sa dá implementovat' prakticky do každého vyučovacieho predmetu. Ciel'om príspevku bolo zistit' od 123 žiakov prvého ročníka SOŠE v Trnave v školskom roku 2019/2020 skúsenosti s absolvovaným predmetom Technika na ich základnej škole a environmentálne témy, s ktorými sa v ňom stretli. Autori tiež zistovali názory žiakov zabsolvovaných hodín Techniky o práci s náradím, nástrojmi a strojmi, o rozvijaní ich tvorivosti návrhmi a výrobou vlastných výrobkov. Realizovaný bol dotaznikový prieskum. Z otázky smerovanej kzisteniu, ako si

\footnotetext{
*Autor pro korespondenci:jana.bilcikova@ukf.sk
} 
pamätajú environmentálne témy preberané v predmete Technika vyplynulo, že 63,3\% respondentov sa neučilo alebo si nepamätajú oblast' environmentálnych tém z vyučovania na hodinách Techniky. Najviac z kladných odpovedi, 12,5\% respondentov, sa vyjadrilo, že zprebraných environmentálnych otázok si pamätajú triedenie odpadu. V závere článku autori poukázali na pričiny, prečo nie sú prierezové témy životného prostredia účinne a názorne na ZŠ implementované a tiež na úlohu učitelov pri zlepšovaní environmentálnej pripravenosti žiakov.

Klúčové slová: environmentálna výchova, predmet Technika, prierezová téma

\section{1 Úvod}

Dnešná doba prináša množstvo environmentálnych výziev, od globálnych, týkajúcich sa zmeny klímy, po lokálne, ktoré sa objavujú ako dôsledky nezodpovedného, nekompetentného správania l'udí voči životnému prostrediu.

Aktuálnym prípadom na Slovensku je vyhlásenie mimoriadnej situácie v súvislosti s toxickým odpadom bývalých chemických závodov Chemko Strážske v januári 2020. V blízkosti areálu sa nachádzajú stovky ton polychlórovaných bifenylov (PCB). Jedná sa o látky zostávajúce $\mathrm{v}$ prostredí, schopné dlhodobého transportu vzduchom alebo vodou do vzdialených oblastí, bioakumulácie $\mathrm{v}$ rastlinných a živočíšnych tkaninách, vrátane l’udských. Vo vyšších koncentráciách môžu poškodit' zdravie l’udí, majú množstvo toxických účinkov, vrátane porúch $\mathrm{v}$ imunitnom a nervovom systéme, reprodukčných anomálií, abnormality $\mathrm{v}$ správaní a pravdepodobnej karcinogenéze (Zmetáková, Šalgovičová, 2006).

Odstránenie takýchto environmentálnych zát’ǎí vyžaduje použitie značných finančných zdrojov z rezerv štátu. Obdobným situáciám je dôležité predchádzat' a to dokážu len environmentálne vzdelaní občania, ktorí si uvedomujú možné následky svojich rozhodnutí a snažia sa závažným situáciám predíst' zodpovedným rozhodovaním.

Už učitelia na školách majú možnost' usmernit' svojich žiakov v tejto oblasti prostredníctvom environmentálnej výchovy a vzdelávania. Tieto majú v zmysle zákona č. 17/1992 Zb. o životnom prostredí uskutočňovat' tak, aby žiakov viedli $\mathrm{k}$ mysleniu a konaniu, ktoré je $\mathrm{v}$ súlade $\mathrm{s}$ princípom trvalo udržatel'ného rozvoja, $\mathrm{k}$ vedomiu zodpovednosti za udržanie kvality životného prostredia a jeho jednotlivých zložiek a k úcte $\mathrm{k}$ životu vo všetkých jeho formách. Pričom trvalo udržatel'ným rozvojom spoločnosti sa podla tohto zákona rozumie taký rozvoj, ktorý súčasným i budúcim generáciám zachováva možnost' uspokojovat' ich základné životné potreby a pritom neznižuje rozmanitost' prírody a zachováva prirodzené funkcie ekosystémov (zákon č. 17/1992 Zb. o životnom prostredí v znení neskorších predpisov).

Jedným z celosvetových ciel'ov je v novej Agende pre trvalo udržatel'ný rozvoj do roku 2030 (Slovenský štatistický úrad, 2016) zabezpečit', že všetci, ktorí sa vzdelávajú, získajú vedomosti a zručnosti potrebné na presadzovanie trvalo udržatel'ného rozvoja, okrem iného aj prostredníctvom vzdelávania k udržatel'nému životnému štýlu, l'udským právam, k rovnosti pohlaví, podpore kultúry mieru a nenásilia, globálneho občianstva a uznania kultúrnej rozmanitosti a príspevku kultúry $\mathrm{k}$ trvalo udržatel'nému rozvoju.

Témy udržatel'ného rozvoja vedú $\mathrm{k}$ zvyšovaniu povedomia $\mathrm{o}$ globálnych environmentálnych problémoch a globálnych problémoch sveta, ktoré sa týkajú každého 
jednotlivca, k rozvoju jeho kritického myslenia a $\mathrm{k}$ hlbšiemu porozumeniu týchto oblastí a tém. Poskytujú priestor na zmenu postojov jednotlivca, skupín, komunít a posilňujú uvedomenie si vlastnej úlohy vo svete (Chrenščová, Škvarková, 2013).

Environmentálna výchova je proces, ktorý umožňuje jednotlivcom skúmat' environmentálne problémy, zapojit' sa do riešenia problémov a podniknút' kroky na zlepšenie životného prostredia. Výsledkom je, že jednotlivci si lepšie uvedomujú environmentálne problémy a majú zručnosti na informované a zodpovedné rozhodovanie (EPA, 2017).

Autori príspevku preto chceli zistit', aké skúsenosti s uplatňovaním environmentálnej výchovy v predmete Technika majú žiaci prvého ročníka na SOŠ elektrotechnickej (d’alej SOŠE) v Trnave zo svojich základných škôl.

\section{Environmentálna výchova v školskom systéme}

Školský systém v Slovenskej republike sa realizuje na základe dvojúrovňového modelu vzdelávania. Prvú úroveň predstavuje záväzný Štátny vzdelávací program (ŠVP). Je východiskom na prípravu školských vzdelávacích programov (ŠkVP), ktoré predstavujú druhú úroveň modelu vzdelávania. Týmto sa dáva možnost' každej škole, aby prostredníctvom využitia volitel'ných (disponibilných) hodín reflektovala vo svojom školskom vzdelávacom programe špecifické regionálne, resp. lokálne podmienky a požiadavky žiakov alebo rodičov (ŠPÚ, 2015).

Vzdelávací štandard heslovito pomenúva učebné obsahy potrebné pre dosiahnutie stanovených výkonov a rozvoj klúčových kompetencií. Pozostáva z charakteristiky predmetu a základných učebných ciel’ov, ktoré sa konkretizujú vo výkonovom štandarde. Je to ucelený systém výkonov, ktoré sú vyjadrené kognitívne odstupňovanými konkretizovanými ciel'mi - učebnými požiadavkami. Tieto základné požiadavky môžu učitelia ešte viac špecifikovat', konkretizovat' a rozvíjat' v podobe d’alších blízkych učebných ciel’ov, učebných úloh, otázok či testových položiek. K vymedzeným výkonom sa prirad’uje obsahový štandard, $v$ ktorom sa zdôrazñujú pojmy ako kl'účový prvok vnútornej štruktúry učebného obsahu. Učivo je v ňom štruktúrované podl'a jednotlivých tematických celkov. Tvorí základ vymedzeného učebného obsahu (ŠPÚ, 2008).

S účinnost'ou od 1.septembra 2015 sú základné školy povinné vzdelávat' podla inovovaného štátneho vzdelávacieho programu (IŠVP) platného od 1. a 5. ročníka Ž̌s. Znamená to, že nami sledovaní žiaci, ktorí nastúpili v školskom roku 2019/2020 do 1. ročníka stredných škôl, ešte neboli vzdelávaní podl’a tohto IŠVP.

Základné požiadavky na vyučovanie environmentálnych pojmov sú obsiahnuté v učebných osnovách, vo vstupných požiadavkách na kvalitu vzdelávania (Feszterová, 2018). Ciel’om prierezovej témy Environmentálna výchova je prispiet' $\mathrm{k}$ rozvoju osobnosti žiaka tak, že v oblasti vedomostí, zručností a schopností nadobudne schopnost' chápat', analyzovat' a hodnotit' vzt'ahy medzi človekom a jeho životným prostredím na základe poznania zákonov, ktorými sa riadi život na Zemi, poznat' a chápat' súvislosti medzi vývojom l'udskej populácie a vzt'ahom $\mathrm{k}$ prostrediu $\mathrm{v}$ rôznych oblastiach sveta, pochopit' súvislosti medzi lokálnymi a globálnymi problémami a vlastnú zodpovednost' vo vzt'ahu k prostrediu (ŠPÚ, 2017).

V Štátnom vzdelávacom programe (ŠPÚ, 2009) platnom od 9/2009 do 8/2015 bola vyučovaciemu predmetu Technika určená $\mathrm{v}$ Rámcovom učebnom pláne (RUP) pre základné školy s vyučovacím jazykom slovenským v rámci vzdelávacej oblasti „Človek a svet práce“ jedna hodina týždenne iba v jednom z 5.-9. ročníka základnej školy. Takto 
mali byt' vzdelávaní aj nami vzdelávaní žiaci. Škola mala na dotvorenie školského vzdelávacieho programu $\mathrm{k}$ dispozícii volitel'né (disponibilné) hodiny, ktoré mohla pridat' na rozšírenie a prehíbenie obsahu vyučovacích predmetov zaradených do štátneho vzdelávacieho programu, napríklad i do predmetu Technika (ŠPÚ - RUP, 2008). Preto skutočný počet hodín jednotlivých predmetov v rámci učebných plánov škôl sa tak mohol líšit'.

\section{Predmet Technika a environmentálna výchova}

Vzdelávací obsah predmetu Technika sa skladal pre všetkých žiakov, ktorí končili 9 ročník najneskôr v roku 2018/2019 podl’a ŠVP z tematických celkov (ŠPÚ, 2009):

- Človek a technika

- Grafická komunikácia

- Materiály a technológie

- Elektrická energia

- Technika-domácnost'-bezpečnost'.

Environmentálne aspekty v týchto tematických celkoch predmetu Technika boli stanovené v rámci niektorých výkonových štandardov, podl’a ktorých žiaci majú:

- vediet' vysvetlit' pojem technika, technické prostredie a technické dielo ako produkt l'udskej činnosti,

- $\quad$ vediet' vymenovat' pozitívne a negatívne dôsledky techniky ${ }^{1}$,

- oboznámit' sa s najvýznamnejšími objavmi a vynálezmi 18. -20. storočia,

- oboznámit' sa s poznatkami histórie na Slovensku a so slovenskými vynálezcami,

- vediet' vysvetlit' pojem technologický postup a opísat' všeobecne cestu vzniku výrobku,

- vediet' realizovat' drobný projekt (zhotovit' technický náčrt, vybrat' vhodný materiál, zvolit’ konštrukčné riešenia a spoje, navrhnút' technológie),

- poznat' proces vzniku technického produktu,

- mat' schopnosti vytvárat' a realizovat' technické myšlienky pre vlastné potreby pre potreby školy, pre komerčné aktivity a pod.,

- poznat' základné druhy technických materiálov,

- vediet' správne preniest' tvar a rozmery predmetu z výkresu na opracúvaný materiál, správne volit' meradlá a pomôcky na obrysovanie,

- vediet' pracovat' podl'a jednoduchého technologického postupu a technického výkresu,

- poznat' a rozlíšit' základné druhy technických materiálov - drevo, kovy, plasty,

- poznat' základné náradie na ručné opracovanie dreva, kovu a plastov,

- prakticky si precvičit' (podl'a možností a vybavenia školy) a osvojit' jednotlivé elementárne zručnosti pri opracovaní dreva, kovov a plastov (pilovanie, vítanie dreva, ohýbanie plastov a plechu, strihanie, sekanie drôtu a plechu),

- poznat základné batériové zdroje elektrickej energie a akumulátory (primárne a sekundárne, elektromechanické - suché a mokré, elektrické - kyslé a alkalické),

${ }^{1}$ Environmentálne témy sú vyznačené hrubým písmom -boldom. 
- vediet' čítat' jednoduché elektrické značky schémy a zapojenia) a vediet' na elektrotechnickej stavebnici pre ZŠ zapájat' jednoduché elektrické obvody,

- poznat základný elektroinštalačný materiál, jeho funkciu a použitie (spínače, vidlice, zásuvky, žiarovkové objímky, poistky a ističe),

- oboznámit' sa s používaním žiarovkovej skúšačky,

- poznat' funkciu a oboznámit'sa s hlavnými parametrami a so správnym používaním základných elektrických spotrebičov pre domácnost',

- $\quad$ vediet' opísat' výrobu a rozvod elektrickej energie a poznat' ekologické aspekty výroby elektrickej energie ${ }^{1}$,

- poznat' význam elektromeru a oboznámit' sa s príkladmi výpočtu spotreby elektrickej energie ${ }^{1}$,

- $\quad$ oboznámit' sa s modernými elektrickými spotrebičmi v domácnosti,

- poznat' pravidlá bezpečnej práce s elektrickým prúdom,

- $\quad$ vediet' poskytnút' prvú pomoc pri úraze elektrickým prúdom.

Pre rozvoj environmentálneho povedomia žiakov autori považujú za významný obsahový štandard tematického celku Technika - domácnost' - bezpečnost'. Obsah učiva bol zameraný na základné informácie v oblasti bytovej inštalácie - kúrenie, rozvod studenej a teplej vody, celkove na domácnost' a úsporu energie, ekologické aspekty a malú údržbu v domácnosti.

Medzi jeho výkonové štandardy patrili:

- Oboznámit' sa so systémom ústredného kúrenia v bytoch a jeho funkciou.

- Vediet' popísat' systém rozvodu studenej a teplej vody v byte.

- Poznat' zloženie a funkciu vodovodného kohútika a jednoduchej vodovodnej batérie.

- Oboznámit' sa s opravou splachovača WC.

- Poznat' možnosti šetrenia teplom a teplou vodou a zároveň spôsoby zamedzenia úniku tepla - spôsoby zateplenia okien a dverí ${ }^{1}$.

- Vediet' popísat' princíp spal'ovania vo vykurovacích zariadeniach - ústredného kúrenia. Poznat' výpočet spotreby energie na kúrenie ${ }^{1}$.

- Ovládat' opravu netesnosti vodovodného kohútika (batérie) výmenou tesnenia, frézovaním sediel alebo výmenou vložiek ventilov (ŠPÚ, 2009).

\section{Ciel' a metodika prieskumu}

Ciel'om autorov bolo zistit' od žiakov skúsenosti s absolvovaným predmetom Technika na ich základnej škole a environmentálne témy, s ktorými sa na ňom stretli.

Pre hromadné a rýchle zist'ovanie informácií o poznatkoch, názoroch alebo postojoch (Novanská, 2017) o výučbe predmetu Technika a otázke prierezovej témy s environmentálnym zameraním bol zvolený dotazníkový prieskum s využitím šiestich otvorených položiek.

Prvá položka prieskumu identifikovala základnú školu, z ktorej žiak (respondent) na SOŠE prišiel študovat'. Štyri položky smerovali k samotnej výučbe predmetu Technika a jedna bola venovaná prierezovej téme environmentálnej výchovy. Dotazníkového prieskumu sa zúčastnilo 123 respondentov na SOŠE v Trnave. Títo uviedli, že sú absolventmi základných škôl z obcí a miest nachádzajúcich sa $\mathrm{v}$ Trnavskom, Trenčianskom a Bratislavskom kraji.

Zámerom takého spôsobu kladenia otázok bolo: 
a) aby si žiaci vybavili v pamäti výučbu predmetu Technika na základnej škole (z hl'adiska absolvovania predmetu, priestorov, výkonu činností na predmete, vlastnej tvorby výrobkov) a tým aj dokázali lepšie reagovat' na spojitost' $\mathrm{s}$ environmentálnou témou,

b) získat' informácie o praktických činnostiach, ktoré boli náplňou predmetu Technika. Respondenti odpovedali anonymne a neboli časovo limitovaní. Znenie jednotlivých položiek bolo formulované s prihliadnutím na ciel'ovú skupinu 15-ročných žiakov absolvujúcich povinnú 10-ročnú školskú dochádzku. Žiaci mali odpovedat' na položky s nasledovným znení:

1. Napište názov základnej školy, ktorú ste absolvovali.

2. Uved'te, v ktorom ročníku ZŠ ste mali vyučovaci predmet Technika.

3. Napište, vakých priestoroch prebiehala výučba predmetu Technika.

4. Vymenujte náradie, nástroje, stroje použivané na hodinách Techniky.

5. Pomenujte výrobky, ktoré ste navrhli alebo vyrobili počas hodin Techniky.

6. Spominate si, aké environmentálne témy (témy v oblasti životného prostredia) ste preberali v rámci výučby predmetu Technika?

Dotazník poslúžil ako prieskumný nástroj získania názorov respondentov v oblasti technického vzdelávania a teda aj informácia o stave a pripravenosti absolventov základných škôl pre d’alšie odborné vzdelávanie žiakov na strednej odbornej škole $\mathrm{s}$ technickým zameraním. Súčasne sa sledovala implementácia prierezovej témy environmentálnej výchovy v predmete Technika.

\section{Interpretácia získaných údajov}

Prvá položka smerovala k zisteniu, akú základnú školu žiaci navštevovali (Obr. č. 1). Otázka bola zámerne postavená tak, aby sa dalo presne identifikovat', či ide o základnú školu v krajskom meste, okresnom meste, meste alebo v obci. Umiestnenie školy v obci by mohlo evokovat' bližší vzt'ah k životnému prostrediu, na druhej strane Trnava ako krajské mesto, patrí k priemyselnejším a teda aj s množstvom environmentálnych problémov, ktoré mohli byt' súčast'ou výučby.

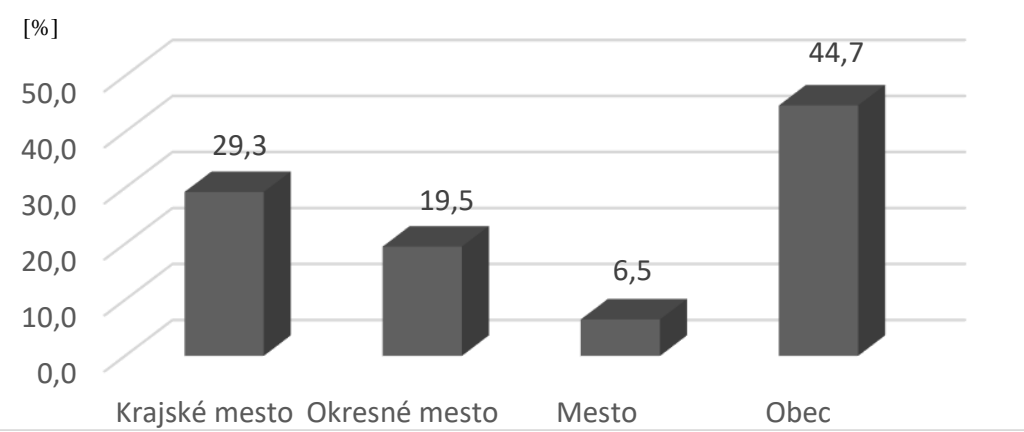

Obr. č. 1: Umiestnenie základnej školy, ktorú žiaci absolvovali. 
Druhou položkou (Obr. č. 2) sme zist’ovali, v kol'kých ročníkoch nižšieho stredného vzdelávania mal ten istý žiak zaradený vyučovací predmet Technika.

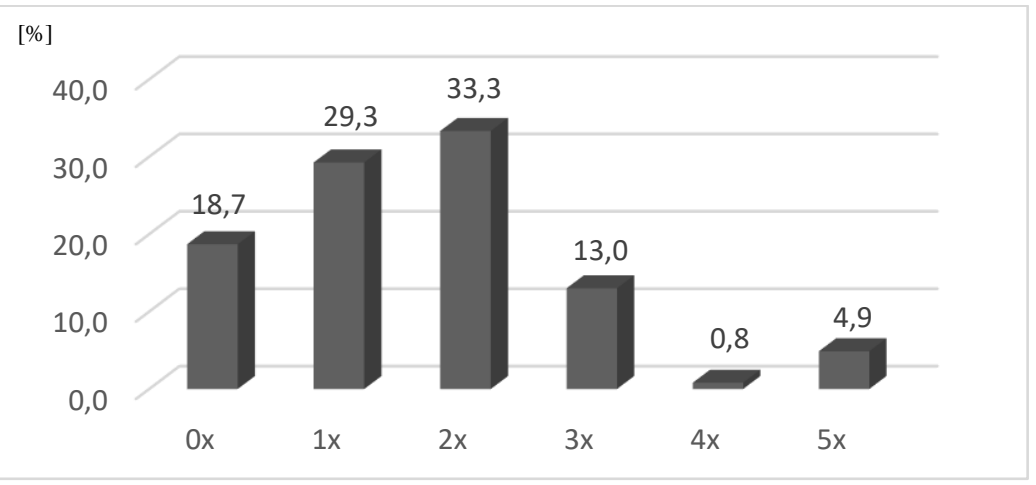

Obr. č. 2: Žiakmi uvádzaný počet absolvovaných rokov štúdia predmetu Technika na Ž̌.

Za závažné považujeme, že takmer $19 \%$ žiakov uviedlo, že v rámci nižšieho stredného vzdelávania vôbec nemali vyučovací predmet Technika. $5 \%$ respondentov prieskumu uviedlo, že vyučovací predmet Technika mali v každom ročníku 2. stupňa ZŠ.

V tretej položke boli identifikované priestory/objekty určené žiakmi ako miesta uskutočňovania predmetu Technika a sú znázornené na obr. č. 3.



Obr. č. 3: Žiakmi uvádzané priestory, v ktorých prebiehala výučba Techniky 1- nemali predmet Technika, 2-trieda, 3-dielňa, 4- údržba areálu a zelene, 5-dielña + areál školy, 6-trieda + dielňa, 7 trieda + areál. 
Nakol'ko žiaci mali možnost' odpovedat' formou otvorených otázok, uviedli aj kombinácie priestorov. Jednoznačne však možno konštatovat', že dielenské priestory si zapamätalo až takmer $31,7 \%$ respondentov.

Štvrtou položkou dotazníka sme zist'ovali, aké náradie a nástroje žiaci používali na hodinách Techniky (Obr. č. 4).



Obr. č. 4: Náradie, nástroje, stroje použivané na hodinách Techniky.

33,3 \% opýtaných uviedlo, že nepoužívali žiadne náradie a nástroje, $19,5 \%$ používalo len záhradné náradie a so strojovým obrábaním sa stretli iba 4 \% žiakov.

Súčast'ou predmetu Technika pri nadobúdaní technických zručností je aj zhotovovanie vlastných výrobkov, ktorých druhy sú na obr. č. 5 .

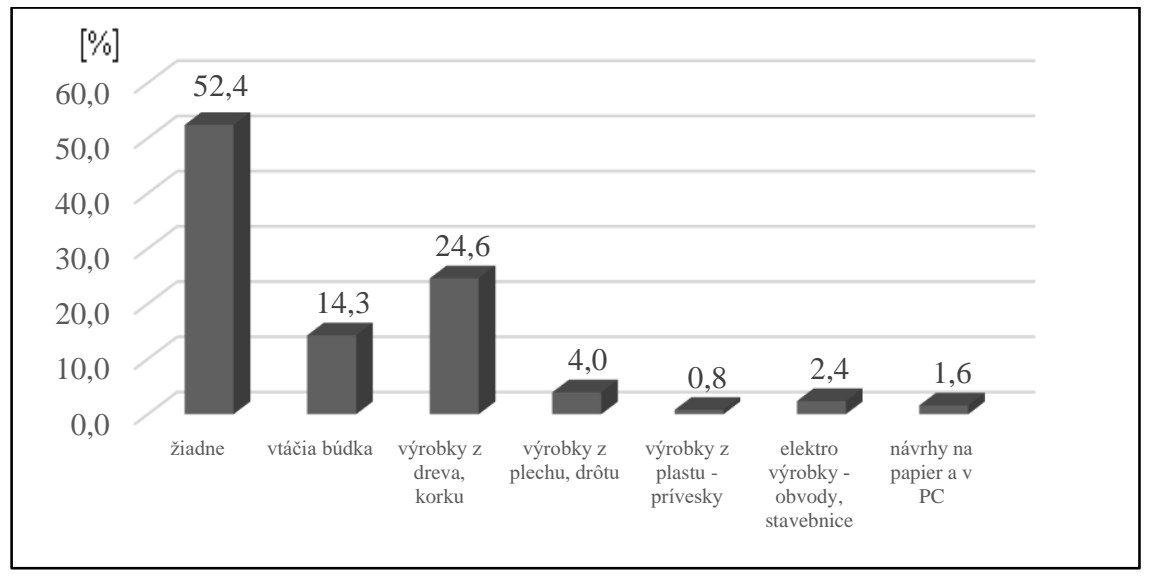

Obr. č. 5: Výrobky, ktoré žiaci navrhli alebo vyrobili na hodinách Techniky. 
V piatej položke 52,4 \% žiakov uviedlo, že nevyrobili na hodinách techniky žiadny vlastný výrobok.

Posledná položka prieskumu smerovala $\mathrm{k}$ tomu, aby si žiaci spomenuli, či na predmete Technika boli včlenené aj témy s environmentálnym podtextom (Obr. č. 6). 63,3\% respondentov uviedlo, že sa neučili alebo si nepamätajú preberanie environmentálnych tém.

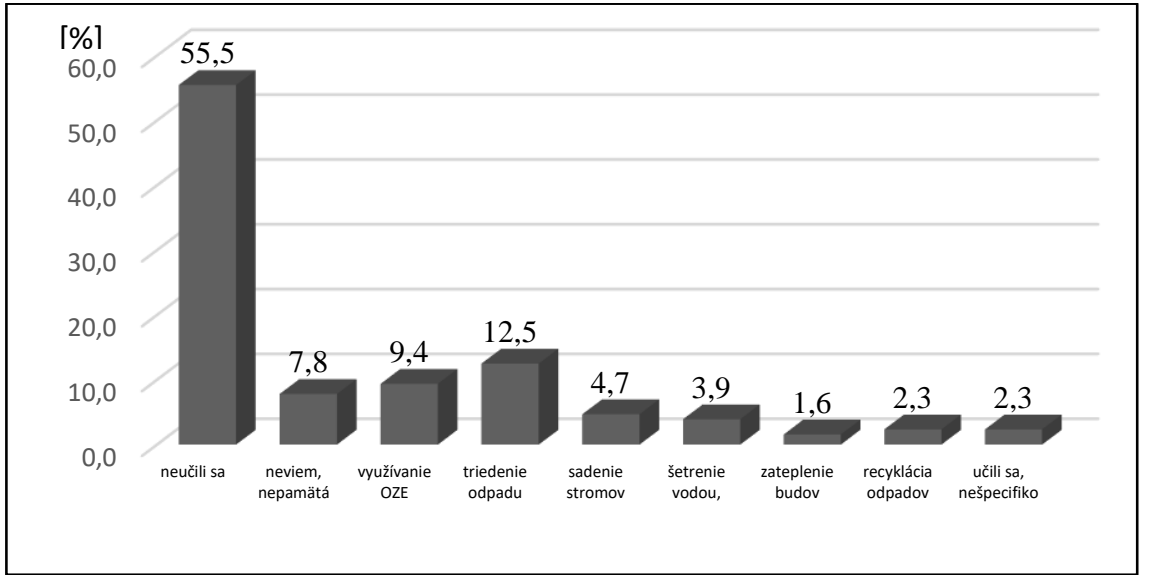

Obrázok 6 Environmentálne témy preberané v rámci výučby predmetu Technika.

\section{Zhodnotenie zisteného stavu}

Z analýzy získaných údajov vyplynulo, že príprava žiakov na základných školách $\mathrm{k}$ technickému mysleniu, $\mathrm{k}$ osvojeniu si základných pracovných zručností a návykov, k používaniu vhodných nástrojov a náradia bola u našich respondentov na nízkej úrovni.

Prieskum u respondentov potvrdil, čo aj vyučujúci učitelia a majstri odbornej výchovy na stredných odborných školách často uvádzajú, slabú pripravenost' žiakov zo ZŠ z technických oblastí života. Pritom v súčasných podmienkach na Slovensku narastá dopyt po technických profesiách na pracovnom trhu. Technická príprava, posudzovaná očami žiakov, bola v niektorých prípadoch vyučujúcimi učitel'mi dokonca zamieňaná s údržbou areálov škôl.

ŠPÚ (2017) uvádza, že ciel’om prierezovej témy Environmentálna výchova je prispiet' $\mathrm{k}$ rozvoju osobnosti žiaka tak, že v oblasti vedomostí, zručností a schopností nadobudne schopnost' chápat', analyzovat' a hodnotit' vzt'ahy medzi človekom a jeho životným prostredím (Činčera, 2012), avšak v skutočnosti sú žiaci zo ZŠ v otázkach dopadov ludskej činnosti a techniky na životné prostredie a alternatívnych možnostiach slabo pripravení, dokonca nepripravení.

Hoci environmentálna výchova je významnou, celospoločensky diskutovanou problematikou, z odpovedí 123 respondentov z vybranej školy možno vyslovit' nasledovné závery:

- 63,3\% žiakov si na environmentálne témy nespomína alebo v Technike sa o environmentálnych problémoch neučili, 
- $12,5 \%$ žiakov si pod environmentálnou problematikou vybavuje triedenie odpadu,

- zvyšné percentá respondentov uviedli využívanie obnovitel'ných zdrojov energie $(9,4 \%)$, výsadbu stromov $(4,7 \%)$, šetrenie vodou a energiou $(3,9 \%)$, recykláciu odpadov $(2,3 \%)$ a zateplenie budov $(1,6 \%)$.

\section{Záver}

Environmentálne témy síce rezonujú v celej spoločnosti a stávajú sa dominantnými, zabezpečeniu kvalitnej výučby na hodinách Techniky v kontexte environmentálnych tém však nie je venovaná dostatočná pozornost'.

Autormi získané výstupy korešpondujú $\mathrm{s}$ výstupmi štúdie, spracovanej $\mathrm{v}$ rámci projektu ESF s názvom „Analýza stavu systému environmentálnej výchovy a vzdelávania v Trenčianskom samosprávnom kraji“ (Špirála, OZ, 2018). Výsledky projektu dospeli v oblasti vzdelávania $\mathrm{v}$ environmentálnej výchove niektorým záverom:

- $\quad$ súčasná inštitucionálna podoba environmentálnej výchovy a vzdelávania v školskom systéme (vo forme prierezovej témy Environmentálna výchova, definovanej v platnom Štátnom vzdelávacom programe) vykazuje znaky nekoncepčnosti a formálnosti,

- chýba moderná koncepcia a systém nielen environmentálnej výchovy a vzdelávania, ale aj celej štátnej environmentálnej politiky (súčasné koncepcie sú už neplatné),

- $\quad$ systém d’alšieho vzdelávania pedagógov je nesystémový a nekoncepčný.

Podl'a reakcií respondentov prieskumu možno predpokladat', že na základných školách je slabá motivácia a nízky záujem učitel’ov o prezentáciu environmentálnych tém. Obmedzené chápanie environmentálnej výchovy, absentujúci systém vzdelávania pedagógov, nedostatočná motivácia a podpora koordinátorov environmentálnej výchovy sú d’alšie otázky, ktoré nastol'uje odborná verejnost'.

Súčasní žiaci základných škôl sa predmet Technika učia už podla inovovaného ŠVP v rozsahu jedna vyučovacia hodina týždenne pät' rokov nižšieho stredného vzdelávania. V rámci vzdelávacích štandardov majú vo výkonových i obsahových štandardoch zahrnuté viaceré environmentálne témy. Avšak na základe aj predložených zistení prieskumu, technike a jej vplyvom na životné prostredie sa na školách nevenuje dostatočná pozornost'. Predmet Technika často vyučujú nekvalifikovaní učitelia, ktorí si dopíňajú týmto predmetom úväzok. Mnoho škôl zrušilo v minulosti školské dielne, a tak i napriek inovovanému vzdelávaciemu štandardu predmetu, stále nemožno z mnohých škôl očakávat' absolventov technicky zdatných, s rozvinutými psychomotorickými zručnost’ami a vyšším environmentálnym povedomím. Faktom však zostáva skutočnost', že ak sú prvky výučby predpísané v ŠVP a taktiež v ŠkVP tieto zamestnanci škôl majú napíñat'. Učitelia by nemali byt' len poskytovatel'om informácií $\mathrm{k}$ problematike, ale svojím environmentálnym správaním a konaním by mali byt' vzorom pre svojich žiakov. Budúcnost' vzdelávania $\mathrm{v}$ danej oblasti bude závisiet' od environmentálnej vyspelosti pedagógov konkrétnych škôl.

Autori súhlasia s konštatovaním (Izakovičová a kol., 2018), že efektívna environmentálna výchova formujúca environmentálne vedomie obyvatel'stva a celej spoločnosti je základom úspešnej implementácie koncepcie trvalo udržatel’ného rozvoja $\mathrm{v}$ reálnej praxi. 


\section{Literatúra}

Činčera, J., Kováčiková, S., Mašková, V., Medal, R., \& Medalová, K. (2012). The Green School: an Impact of Evaluation on Decision-Making about a Program. The New Educational Review, 30(4), 17-29.

EPA (2017). Environmental Education (EE). Dostupné z: https://www.epa.gov/education Feszterová, M. (2018). Interdisciplinary approach and implementation of modern trends into the education in the category waste. Journal of Technology and Information Education, 10(2).

Chrenščová, V., \& Škvarková, J. (2013). Hodnotenie uplatňovania myšlienky udržatel'ného rozvoja vo výchovno-vzdelávacom procese na základných školách v meste Banská Štiavnica. Envigogika, 8(1). DOI: 10.14712/18023061.291

Izakovičová, Z. a kol. (2018). Environmentálna výchova v zmysle koncepcie trvalo udržatel'ného rozvoja. Zborník príspevkov z národnej konferencie environmentálna výchova, vzdelávanie a osveta $v$ Slovenskej republike. Nitra.

Novanská, V. (2017). Postoje učitel'ov k využívaniu aktivizujúcich metód v environmentálnej výchove na základných školách. Biológia, Ekológia, Chémia, 21(1).

Slovenský štatistický úrad. (2016). Slovenská republika a ciele udržatel'ného rozvoja AGENDY 2030. Bratislava.

Špirála, OZ (2018). Analýza stavu systému environmentálnej výchovy a vzdelávania v Trenčianskom samosprávnom kraji. Dostupné na:

https://www.minv.sk/swift_data/source/rozvoj_obcianskej_spolocnosti/participacia/vyst upy_np_parti/PP3-

$\% 20$ Analyza $\% 20$ stavu $\% 20$ systemu $\% 20$ envronmentalnej\%20vychovy $\% 20 \mathrm{a} \% 20 \mathrm{vzdelav}$ ania\%20v\%20TSK.pdf

ŠPÚ $\quad-\quad$ RUP. $\quad$ (2008). Dostupné http://www.statpedu.sk/files/articles/dokumenty/statny-vzdelavaci-program/rup2.pdf

ŠPÚ. (2009). Štátny vzdelávací program pre 2. stupeň základnej školy v Slovenskej republike ISCED $2-$ nižšie sekundárne vzdelávanie. Dostupné na: http://www.statpedu.sk/files/articles/dokumenty/statny-vzdelavaci-

program/isced2_spu_uprava.pdf

ŠPÚ - Technika. (2009). Technika - nižšie stredné vzdelávanie. PRÍLOHA ISCED 2. Dostupné na: http://www.statpedu.sk/files/articles/dokumenty/statny-vzdelavaciprogram/technika_isced2.pdf

ŠVP. (2015). Štátny vzdelávací program nižšie stredné vzdelávanie - 2. stupeň základnej školy. Dostupné z: http://www.statpedu.sk/files/articles/dokumenty/inovovany-statnyvzdelavaci-program/svp_nsv_6_2_2015.pdf

ŠPÚ. (2017). Metodické usmernenie k zavádzaniu prierezových tém do školských vzdelávacích programov. Dostupné na: http://www.statpedu.sk/sk/aktuality/metodickeusmernenie-k-zavadzaniu-prierezovych-tem-do-skolskych-vzdelavacich-

programov.html

MŠVVaŠ SR: Vzdelávacie štandardy pre 2. stupeň ZŠ. Dostupné na: https://www.minedu.sk/vzdelavacie-standardy-pre-2-stupen-zs/ 
ŠPÚ. (2017). Metodické usmernenie k zavádzaniu prierezovej témy do iŠkVP. Dostupné na: $\quad$ http://www.statpedu.sk/files/sk/metodicky-portal/metodickepodnety/env metodicke usmernenie.pdf

Zákon č. 17/1992 Zb. Zákon o životnom prostredí v znení neskorších predpisov, Dostupné na: https://www.zakonypreludi.sk/zz/1992-17

Zmetáková, Z., Šalgovičová, D. (2006). Polychlórovanými bifenyly, životné prostredie a člověk. TRENDY $v$ potravinárstve, 13(1). Dostupné na: https://www.enviroportal.sk/ism/pdf/cudzorode-latky/PCB_ZP_clovek.pdf 